\title{
Analisis Metode Pengakuan Pendapatan Dan Beban Atas Perusahaan Real Estate Pada PT. Maura Lombok Sesuai Dengan PSAK No. 44
}

\author{
Dewa Ayu Oki Astarini, M.Ak
}

Universitas Bumigora

astarini.oki@universitasbumigora.ac.id

\begin{abstract}
Abstrak
Penelitian ini dilakukan di PT Maura Lombok yang merupakan perusahaan properti yang mengelola bidang pengembangan perumahan, tanah kavling dan, pembangunan (kontraktor). Penelitian ini bertujuan untuk mengetahui apakah metode pengakuan pendapatan dan beban PT Maura Lombok sesuai dengan Pernyataan Standar Akuntansi Keuangan (PSAK) No.44 dan melakukan perhitungan pengakuan pendapatan dan beban PT Maura Lombok dengan persentase penyelesaian. Metode penelitian yang digunakan yaitu penelitian deskriptif kuantitatif, jenis data yang digunakan adalah data sekunder. Metode deskriptif kuantitatif digunakan untuk mengetahui apakah metode pengakuan pendapatan yang diakui oleh perusahaan sudah sesuai dengan PSAK 44 dan melakukan penyajikan kembali pengakuan pendapatan dan beban dengan menggunakan metode peresentase penyelesaian yang akan diungkapkan pada laporan laba rugi PT Maura Lombok. Hasil pengamatan yang dilakukan terhadap metode pengakuan pendapatan dan beban pada PT Maura Lombok adalah PT Maura Lombok mengakui pendapatan dan bebannya dengan menggunakan metode akrual penuh, berdasarkan PSAK No. 44 seharusnya PT Maura Lombok menggunakan metode persentase penyelesaian. Terdapat perbedaan antara pendapatan dan beban pokok penjualan perusahaan dengan metode yang sebelumnya digunakan perusahaan yaitu metode akrual (full accrual method) penuh dengan metode yang seharusnya digunakan perusahaan sesuai dengan PSAK No. 44 yaitu metode persentase penyelesaian.
\end{abstract}

\section{Kata Kunci : full accrual method, percentage of completion method, pendapatan dan beban}

\begin{abstract}
Abstrak
This research was conducted at PT Maura Lombok which is a property company that manages the field of residential development, kavling land and, development (contractor). This research aims to find out if the method of recognition of income and expenses of PT Maura Lombok in accordance with the Statement of Financial Accounting Standards (PSAK) No.44 and to calculate the recognition of income and expenses of PT Maura Lombok with a percentage of completion method. The research method used is quantitative descriptive research, the type of data used is secondary data. Quantitative descriptive methods are used to determine whether the revenue recognition method recognized by the company is in accordance with PSAK 44 and re-check the recognition of income and expenses by using the percentage of completion method that will be disclosed in pt Maura Lombok's income statement. The result of observations made on the method of recognition of income and expenses at PT Maura Lombok is that PT Maura Lombok recognizes its income and expenses by using the full accrual method, based on PSAK No. 44 should PT Maura Lombok use percentage of completion method. There is a difference between the revenue and the principal expense of the sale of the company and the method previously used by the company, namely the full accrual method (full accrual method) full of methods that the company should use in accordance with PSAK No. 44 which is the percentage of completion method.
\end{abstract}

Keywords : full accrual method, percentage of completion method, income and expenses 


\section{Pendahuluan}

Dunia Properti di Indonesia sedang berkembang dengan pesat seiring dengan kebutuhan terhadap perumahan rakyat yang semakin besar dan pertumbuhan ekonomi yang semakin baik. Hal ini juga didukung dengan daya tarik masyarakat yang membeli property tidak hanya sebagai kebutuhan tapi juga investasi masa depan. Properti investasi adalah properti untuk menghasilkan kenaikan nilai dan tidak untuk digunakan dalam hal dijual dalam kegiatan sehari-hari serta digunakan dalam produksi (Indonesia, Ikatan Akuntan 2011). Minat masyarakat yang cukup besar untuk memiliki property untuk hunian ataupun investasi menjadi peluang besar bagi perusahaan pengembang untuk mengembangkan bisnis mereka dalam hal penyediaan sarana pemukiman bagi masyarakat seperti perumahan baik itu subsidi dan komersil. Menurut Ikatan Akuntan Indonesia / IAI (2012) di dalam PSAK No. 44 dijelaskan bahwa perusahaan pengembang adalah perusahaan yang melakukan aktivitas pengembang real estate. Aktivitas pengembangan real estate adalah kegiatan perolehan tanah untuk kemudiaan dibangun perumahan dan/atau bangunan komersial dan/atau bangunan industri. Bangunan tersebut dimaksudkan untuk dijual atau disewakan sebagai suatu kesatuan atau retail (Hajar, 2020).

Penjualan tersebut adalah pendapatan yang merupakan bagian penting dari perusahaan dalam menjalankan usahanya. Pendapatan dapat dilihat dalam laporan laba rugi yang merupakan salah satu bagian dari laporan keuangan perusahaan. Penerapan suatu kebijakan akuntansi yang sesuai dengan PSAK dapat dilihat dengan cara penyajian bentuk laporan keuangan yang merupakan bagian dari salah satu tanggung jawab manajemen suatu badan usaha kepada pihak yang berkepentingan, seperti kepada para pemegang saham, kreditur, karyawan, atau mitra usaha yang membutuhkan informasi yang bersifat terukur secara moneter dalam suatu periode operasi suatu perusahaan. Bersifat terukur karena dalam suatu periode usaha normal yaitu dalam kurun waktu 1 tahun, dan setiap unsur yang tercantum dalam laporan keuangan menggunakan jenis satuan yang jelas yaitu mata uang yang berlaku, sehingga pengguna informasi baik pihak internal maupun eksternal memiliki referensi yang kuat dalam menganalisa laporan tersebut berdasarkan kondisi yang berlaku saat penyajian suatu laporan keuangan. Salah satu elemen penting dalam laporan keuangan adalah pendapatan (Zuhriyah,2019). Pengakuan pendapatan perusahaan yang bergerak dibidang pengembangan real estate harus mengacu kepada Pernyataan Standar Akuntansi Keuangan (PSAK) Nomor 44. PSAK No. 44 menyebutkan bahwa pengakuan penjualan unit real estate dapat diakui dengan beberapa metode antara lain metode akrual penuh (full accrual method), metode deposit (deposit method), dan metode persentase penyelesaian (percentage of completion method).

Metode pengakuan pendapatan yang dijelaskan dalam PSAK No.44 pada penerapan harus disesuaikan dengan jenis perusahaan karena pnggunaan metode yang tidak tepat dalam pengakuan pendapatan berakibat pada laporan keuangan yang menjadi tidak andal dan tidak bisa menjadi acuan atau sumber informasi bagi pengguna laporan keuangan. Perusahaan konstruksi memiliki karakteristik yang khas dalam menjalankan proses kerja proyeknya, dimana proyek yang dikerjakan membutuhkan waktu bervariasi sehingga tidak selalu selesai dalam satu periode akuntansi. Metode akuntansi yang dapat digunakan untuk mengakui pendapatan pada perusahaan konstruksi yaitu metode persentase penyelesaian. Dengan metode persentase penyelesaian perusahaan akan mengakui pendapatan dan beban sesuai dengan tingkat kemajuan penyelesaian kontrak dan tidak menunggu sampai kontrak diselesaikan. Jumlah pendapatan yang diakui didasarkan pada ukuran tertentu dari kemajuan penyelesaian kontrak. Pengukuran ini memerlukan suatu taksiran mengenai biaya-biaya yang harus dikeluarkan.Kelebihan dari metode persentase penyelesaian yaitu mengakui pendapatan atas dua proyek sebelum kontrak tersebut diselesaikan, sehingga 
informasi yang tepat waktu dapat disajikan. Penggunaan metode pengakuan pendapatan yang telah sesuai dengan standar membuat sebuah laporan keuangan dapat diakui keandalanya oleh pihak yang berkepentingan untuk pengambilan keputusan dan bagi pihak-pihak lain yang membutuhkan informasi.

Penelitian ini merupakan pengembangan dari penelitian yang dilakukan Hajar (2016) mengenai Analisis Metode Pengakuan Pendapatan Dan Beban Atas Perusahaan Real Estate Pada PT XYZ Sesuai Dengan PSAK No. 44. Hasil pengamatan yang dilakukan terhadap metode pengakuan pendapatan dan beban pada PT XYZ adalah PT XYZ mengakui pendapatan dan bebannya dengan menggunakan metode akrual penuh (full accrual method), berdasarkan PSAK No. 44 seharusnya PT XYZ menggunakan metode persentase penyelesaian (percentage of completion method). Terdapat perbedaan antara pendapatan dan beban pokok penjualan perusahaan dengan metode yang sebelumnya digunakan perusahaan yaitu metode akrual penuh dengan metode yang seharusnya digunakan perusahaan sesuai dengan PSAK No. 44 yaitu metode persentase penyelesaian.Beberapa peneliti yang mendukung penelitian ini antara lain dilakukan oleh Firdatus Zuhriyah (2019) mengenai Analisis Penerapan Akuntansi PengakuanPendapatan pada Perusahaan Properti "PT. Rojoland Indonesia Build". Pada objek penelitian Firdatus Zuhriyah (2019)yang dilakukan oleh yang masih menggunakan metode cash basis. Hasil penelitian menunjukanPT. Rojoland Indonesia Build belum tepat dalam mengakui pendapatannya karena down payment (DP), angsuran pada saat penerimaan diakui langsung sebagai pendapatan bagi perusahaan. Perusahaan belum bisa menggunakan metode akrual (accrual method) karena salah satu kriteria dalam menggunakan metode akrual belum terpenuhi. Hal ini bisa dilihat pada saat pembayaran uang muka angsuran pertama sampai angsuran kedua belum mencapai $20 \%$ dari harga jual. Salah satu kriteria dalam menggunakan metode akrual adalah harga jual akan tertagih. Harga jual akan tertagih apabila jumlah pembayaran oleh pembeli setidaknya mencapai $20 \%$ dari harga jual.

Dewi (2007) mengungkapkan mengenai akuntansi aktivitas pengembangan real estate menurut PSAK No.4, pada PT. Ira Widya Utama Medan yang menggunakan metode akrual penuh (full accrual method) sebagai metode pengakuan pendapatan untuk penjualan tanah dan bangunan rumah serta penjualan tanah matang. Sedangkan, pada penjualan unit serta bangunan perkantoran menggunakan metode presentase penyelesaian. Tri Wahyudi (2003) mengenai pengakuan pendapatan dan biaya pada PT. Pembangunan Perumahan Cabang V Semarang menunjukkan prosedur pencatatan akuntansi pendapatan dan biaya yang digunakan dalam pembiayaan proyek menggunakan presentase penyelesaian (percentage of completion method). Dalam metode ini semua biaya yang dikeluarkan untuk pembangunan dicatat dalam rekening bangunan dalam pelaksanaan. Setiap akhir periode dilakukan perhitungan laba atau rugi berdasarkan presentase penyelesaian.

PT. Maura Lombok merupakan salah satu perusahaan property yang sedang berkembang di Nusa Tenggara Barat yang berkedudukan di Kota Mataram. Sebagain besar perumahan subsidi yang dijual oleh PT. Maura Lombok berlokasi di Kabupaten Lombok Barat seperti Narmada dan Gerung. Sebagai perusahaan property PT. Maura Lombok memperoleh pendapatan dari penjualan perumahan subsidi. PT. Maura Lombok mengakui pendapatan dan beban sudah sesuai dengan penerapan PSAK 44 dengan menggunakan metode akrual penuh (full accrual method). Berdasarkan uraian tersebut penulis tertarik untuk mengetahui apakah penerapan metode pengakuan laba yang digunakan PT. Maulana Raya Lombok menggunakan metode akrual penuh (full accrual method) telah sesuai dengan kriteria-kriteria yang ditetapkan dalam PSAK No. 44, karena apabila perusahaan salah dalam menerapkan metode pengakuan pendapatan dan beban 
tersebut, maka akan berdampak pada laporan keuangan PT. Maura Lombok yang disajikan secara tidak proporsional dengan keadaan perusahaan yang sebenarnya.

\section{Tinjauan Pustaka}

Menurut FASB (Financial Accounting Standard Board) yang dikemukakan oleh Imam Ghozali dan Anis Chariri (2014:326) "Pendapatan adalah arus masuk atau peningkatan nilai asset dari suatu entitas atau penyelesian kewajiban dari entitas atau gabungan keduanya selama periode tertentu yang berasal dari penyerahan atau produksi barang, pemberian jasa atas pelaksana kegiatan lainnya yang merupakan kegiatan utama perusahaan yang sedang berjalan. Pengertian pendapatan (revenue) sering disamakan dengan istilah penghasilan (income), tetapi sebenarnya istilah tersebut berbeda. Perbedaannya dijelaskan dalam definisi sebagai berikut: "Penghasilan didefinisikan sebagai peningkatan manfaat ekonomi selama periode akuntansi dalam bentuk arus masuk atau peningkatan asset atau penurunan liabilitas yang mengakibatkan kenaikan ekuitas, yang tidak berasal dari kontribusi penanaman modal. Penghasilan (income) meliputi pendapatan (revenue) maupun keuntungan (gain).

Apabila dilihat dari hubungan artikulasi laporan keuangan, pengertian pendapatan sebagai kenaikan aktiva kotor akan lebih berguna daripada pengertian pendapatan yang didasarkan pada konsep neto. Atas dasar artikulasi tersebut, pendapatan dapat didefinisikan sebagai kenaikan aktiva atau penurunan hutang. Jadi, pendapatan merupakan kenaikan aktiva perusahaan dan bukan kenaikan kekayaan pemilik. IAI sendiri memiliki pengertian pendapatan yang tidak jauh berbeda. Dalam PSAK No.23 tentang Pendapatan, dijelaskan bahwa yang dimaksud pendapatan adalah : arus masuk bruto dari manfaat ekonomi yang timbul dari aktivitas normal suatu perusahaan selama satu periode bila arus masuk tersebut mengakibatkan kenaikan ekuitas, yang tidak berasal dari kontribusi penanaman modal.

Menurut Smith dan Skousen (2004:313) sifat-sifat pendapatan dapat dilihat dari defenisi pendapatan yaitu setiap arus masuk atau pertambahan aktiva dari satuan badan atau pelunasan kewajiban (kombinasi dari keduanya) melalui kiriman atau menghasilkannya suatu barang, jasa atau aktivitas lain yang diberi merupakan kegiatan utama perusahaan. Jadi sifat pendapatan adalah sebagai arus masuk aktiva kedalam perusahaan dan sebagai arus keluarnya barang dan jasa melalui perusahaan. Karena barang dan jasa harus dikirim ke pelanggan melalui transaksi penjualan. Sifat pendapatan dapat juga sebagai produk dari suatu perusahaan, karena barang dan jasa yang dikirim pelanggan pada dasarnya diperoleh atau dihasilkan oleh perusahaan. Menurut Standar Akuntansi Keuangan (2017:44.1) PSAK No. 44 Aktivitas Pengembang Real Estate merupakan kegiatan dari perolehan tanah yang kemudian dibangun perumahan dan/atau bangunan komersial dan/atau bangunan industri. Bangunan yang dimaksud untuk dijual atau disewakan, sebagai satu kesatuan atau biasanya secara eceran (retail). Aktivitas Pengembang Real Estate juga meliputi perolehan tanah kavling untuk dijual tanpa bangunan.

Perusahaan pengembang merupakan perusahaan yang melaksanakan aktivitas pengembangan real estate. Unit bangunan merupakan unit properti dari perumahan dan/atau komersial dan/atau industri beserta kavling tanahnya. Proyek merupakan semua unit bangunan yang pembangunannya di suatu area geografis, termasuk kaving tanah kosong untuk dijual. Unit real estate mencangkup (a) unit properti perumahan dan/atau komersial dan/atau industri beserta kavling tanahnya, dan (b) kavling tanah tanpa bangunan. Pengikatan suatu jual beli merupakan kesempatan diantara pihak pembeli dan pihak penjual untuk melakukan perjanjian jual beli atau biasanya lebih unit real estat pada periode mendatang, sejak tanggal ditandatangani, kedua beah pihak telah terikat oleh 
kesepakatan tersebut sesuai dengan hak dan kewajiban setiap pihak. Keterlibatan Penjual Tanpa Pengalihan Risiko dan Manfaat Kepemilikan masih ada, apabila:

a. Penjual masih akan terlibat secara signifikan dengan unit bangunan yang dijual dan tidak mengalihkan, secara signifikan, risiko dan manfaat kepemilikan unit bangunan yang telah dijual.

b. Penjual menjamin hasil yang akan diperoleh pembeli dari hasil investasinya atau menjamin hasil atas investasi tersebut untuk suatu periode tertentu.

c. Penjual diharuskan untuk memulai atau mendukung kegiatan atau terus mengoperasikan unit bangunan atas risiko sendiri, atau dapat dianggap menanggung risiko, tersebut untuk suatu periode tertentu.

Menurut Donald E. Kieso dan Jerry J. Weygandt (2011;955) Prinsip pengakuan pendapatan menetapkan bahwa pendapatan diakui pada saat direalisasi atau dihasilkan. Pendapatan direalisasi apabila barang-barang dan jasa-jasa tersebut dipertukarkan untuk kas atau diklaim atas kas (piutang). Pendapatan bisa direalisasi apabila aktiva yang diterima segera dapat dipindahkan atau dikonversikan pada jumlah kas atau klaim atas kas yang diketahui. Dan pendapatan yang dihasilkan bila satuan tersebut sebagian besar telah menyelesaikan yang seharusnya dilakukan supaya berhak atas manfaat yang diberikan dari pendapatan, yaitu bila proses mencari laba telah selesai atau sebenarnya telah selesai. Sesuai dengan prinsip tersebut maka :

1. Pendapatan dari penjualan produk diakui saat tanggal penjualan, yang terkadang diinterpretasikan berarti tanggal pengiriman kepada pelanggan.

2. Pendapatan dari jasa yang diberikan diakui ketika jasa-jasa telah dilaksanakan dan dapat ditagih.

3. Pendapatan dari memberi kemungkinan bagi pihak lainnya untuk menggunakan aktiva perusahaan, seperti bunga, sewa dan royalti, diakui pada saat waktu yang berlalu atau saat aktiva itu digunakan.

4. Pendapatan dari pelepasan aktiva selain produk diakui pada tanggal penjualan.

Menurut Standar Akuntansi Keuangan (2017:44.1) PSAK No. 44 Aktivitas Pengembang Real Estat merupakan kegiatan dari perolehan tanah yang kemudian dibangun perumahan dan/atau bangunan komersial dan/atau bangunan industri. Perusahaan pengembang merupakan perusahaan yang melaksanakan aktivitas pengembangan real estate (Zuhriyah,2019). Unit real estate mencangkup (a) unit properti perumahan dan/atau komersial dan/atau industri beserta kavling tanahnya, dan (b) kavling tanah tanpa bangunan. Menurut Kieso, Weygant, dan Warfield (2011 : 955) Prinsip pengakuan pendapatan menetapkan bahwa pendapatan diakui pada saat direalisasi atau dihasilkan.Menurut Standar Akuntansi Keuangan (2017:44.2) PSAK No. 44 tentang akuntansi pengembangan real estate, metode yang digunakan untuk pengakuan pendapatan pada penjualan bangunan ruo, rumah dan bangunan sejenis lainnya beserta tanah kavlingnya dan penjualan tanah kavling tanah tanpa bangunan ini adalah metode akrual penuh (full accrual method), metode deposit (deposit method) dan presentase penyelesaian (percentage-of-completion method).

\section{a. Metode Akrual Penuh (Full Accrual Method)}

Pendapatan penjualan suatu bangunan ruko, rumah dan bangunan sejenis lainnya beserta tanah kavling tanahnya yang diakui dengan metode akrual penuh (full accrual method) jika seluruh kriteria berikut ini terpenuhi: Proses penjualan telah selesai;

1. Harga jual akan tertagih;

2. Tagihan penjual tidak akan bersifat subordinasi di masa mendatang terhadap pinjaman lain yang akan didapat oleh pembeli; 
3. Penjual telah mengendalikan resiko dan manfaat kepemilikan terhadap unit bangunan kepada pembeli melalui suatu jenis transaksi yang secara substansi yaitu penjualan dan penjual tidak lagi berkewajiban atau terlibat secara signifikan dengan unit bangunan tersebut;

b. Metode Deposit (Deposit Method)

Apabila suatu transaksi real estat tidak memenuhi kriteria pengakuan laba dengan menggunakan metode akrual penuh, pengakuan penjualan ditangguhkan dan transaksi tersebut akan diakui dengan metode deposit (deposit method) hingga seluruh kriteria yang menggunakan metode akrual penuh terpenuhi. Penerapan metode deposit yaitu sebagai berikut :

1. Penjual tidak mengakui pendapatan atas transaksi penjualan unit real estate, dan penerimaan pembayaran oleh pembeli dibukukan sebagai uang muka;

2. Piutang dari transaksi penjualan suatu unit real estat tidak diakui;

3. Unit real estate tersebut tetap dicatat sebagai aktiva penjual, demikian juga dengan kewajiban yang terkait dengan unit real estate tersebut, walaupun kewajiban tersebut telah dialihkan kepembeli;

4. Khusus unit real estate penyusutan dalam unit real estat tersebut tetap diakui oleh penjual.

c. Metode presentase penyelesaian (percentage-of-completion method)

Pendapatan penjualan unit bangunan kondominium, apartemen, perkantoran, pusat perbelanjaan dan bangunan sejenis lainnya, serta unit dalam kepemilikan secara time sharing, diakui dengan menggunakan metode presentase penyelesaian (percentage-of-completion method) apabila seluruh kriteria berikut ini terpenuhi proses konstruksi telah melampui tahap awal, yaitu fondasi bangunan telah selesai dalam semua persyaratan untuk memulai bangunan telah dipenuhi;

a. proses konstruksi telah melampui tahap awal, yaitu fondasi bangunan telah selesai dalam semua persyaratan untuk memulai bangunan telah dipenuhi;

b. jumlah pembayaran oleh pembeli telah mencapai $20 \%$ dari harga jual yang telah disepakati dan jumlah tersebut tidak dapat diminta kembali oleh pembeli;

c. jumlah pendapatan penjualan dan biaya unit bangunan dapat diestimasi dengan andal.

Aktivitas pengembangan real estate apabila dikondisikan seperti penjelasan tersebut, metode persentase penyelesaian (precentage-of-completion method) merupakan metode akuntansi yang dapat digunakan oleh aktivitas pengembangan real estate. Penggunaan metode persentase penyelesaian dapat menjadi dasar pengakuan pendapatan karena dapat memberikan informasi yang berguna bagi pengguna laporan keuangan, hal tersebut diakui secara proposional untuk jumlah pendapatan dengan jumlah beban untuk menghasilkan pendapatan. (Indonesia, Ikatan Akuntan 2018b).

Berikut beberapa peneliti yang mendukung penelitian ini antara lain yaitu dilakukan oleh Hajar (2016) mengenai Analisis Metode Pengakuan Pendapatan Dan Beban Atas Perusahaan Real Estate Pada PT XYZ Sesuai Dengan PSAK No. 44. Hasil pengamatan yang dilakukan terhadap metode pengakuan pendapatan dan beban pada PT XYZ adalah PT XYZ mengakui pendapatan dan bebannya dengan menggunakan metode akrual penuh (full accrual method), berdasarkan PSAK No. 44 seharusnya PT XYZ menggunakan metode persentase penyelesaian (percentage of completion method). Terdapat perbedaan antara pendapatan dan beban pokok penjualan perusahaan dengan metode yang sebelumnya digunakan perusahaan yaitu metode akrual penuh dengan metode yang seharusnya digunakan perusahaan sesuai dengan PSAK No. 44 yaitu metode 
persentase penyelesaian (percentage of completion method).

Firdatus Zuhriyah (2019) mengenai Analisis Penerapan Akuntansi PengakuanPendapatan pada Perusahaan Properti "PT. Rojoland Indonesia Build" .Pada objek penelitian Firdatus Zuhriyah (2019)yang dilakukan oleh yang masih menggunakan metode cash basis. Hasil penelitian menunjukan PT. Rojoland Indonesia Build belum tepat dalam mengakui pendapatannya karena down payment (DP), angsuran pada saat penerimaan diakui langsung sebagai pendapatan bagi perusahaan. Perusahaan belum bisa menggunakan metode akrual (accrual method) karena salah satu kriteria dalam menggunakan metode akrual belum terpenuhi. Hal ini bisa dilihat pada saat pembayaran uang muka angsuran pertama sampai angsuran kedua belum mencapai $20 \%$ dari harga jual. Salah satu kriteria dalam menggunakan metode akrual adalah harga jual akan tertagih. Harga jual akan tertagih apabila jumlah pembayaran oleh pembeli setidaknya mencapai $20 \%$ dari harga jual.

Andolita Shinta Dewi (2007) yang meneliti mengenai akuntansi aktivitas pengembangan real estate menurut PSAK No.44 pada PT. Ira Widya Utama Medan. Hasil penelitian pada PT. Ira Widya Utama Medan menggunakan metode akrual penuh (full accrual method) sebagai metode pengakuan pendapatan untuk penjualan tanah dan bangunan rumah serta penjualan tanah matang. Sedangkan, pada penjualan unit serta bangunan perkantoran menggunakan metode presentase penyelesaian.

Tri Wahyudi (2003) melakukan penelitian mengenai pengakuan pendapatan dan biaya pada PT.Pembangunan Perumahan Cabang V Semarang. Hasil penelitian ini adalah prosedur pencatatan akuntansi pendapatan dan biaya yang telah digunakan dalam pembiayaan proyek menggunakan presentase penyelesaian. Dalam metode ini seluruh biaya yang dikeluarkan untuk pembangunan dicatat ke rekening bangunan dalam pelaksanaan. Setiap akhir periode dilakukan perhitungan suatu laba atau rugi berdasarkan presentase penyelesaian.

\section{METODE PENELITIAN}

Data dalam penulisan ini didapat dari KAP PAS yang beralamat di Jalan Lingkar. Nama KAP bukanlah nama perusahaan sebenarnya, sesuai dengan permintaan KAP Metode pengumpulan data yang digunakan adalah data sekunder yang didapat melalui perantara. Nama Perusahaan PT. Maura Lombok Bukanlah nama perusahaanya, sesuai dengan permintaan dari perusahaan.Data yang diperoleh berupa laporan keuangan PT.Maura Lombok tahun 2019, proyeksi pendapatan dan beban, dan laporan progress penyelesaian. Metode analisis data yang digunakan penulis adalah metode deskriptif dan kuantitatif. Tahapan dalam pelaksanaan analisis metode pengakuan pendapatan adalah mengungkapkan metode pengakuan pendapatan dan beban PT Maura apakah sesuai dengan PSAK No. 44, melakukan penyanyian kembali pengakuan pendapatan sesuai dengan PSAK No. 44, dan membuat jurnal penyesuaian.

\section{HASIL DAN PEMBAHASAN}

Pendapatan operasional PT.Maura Lombok berasal dari aktivitas pengembangan real estate yaitu penjualan atas Rumah Subsidi Sedayu. Pembayaran rumah subsidi Sedayu menggunakan 2 metode pembayaran yaitu dengan KPR dan cash bertahap. Berdasarkan laporan laba rugi PT.Maura periode 31 Desember 2019 pendapatan yang telah diterima perusahaan sebesar Rp. 19.387.057.570, dan biaya yang telah dikeluarkan perusahaan sebesar Rp.15.026.026.837. Biaya yang dikeluarkan perusahaan tersebut terdiri dari biaya untuk membangun fondasi bangunan, dan proses kontruksi tersebut telah selesai dikerjakan. Semua biaya yang dikeluarkan perusahaan dalam membangun Rumah Subsidi Sedayu di kapitalisasi ke dalam akun persediaan. Metode yang digunakan oleh PT.Maura 
Lombok dalam mengakui pendapatan dan beban sudah sesuai dengan pengakuan pendpatan sesuai dengan PSAK No. 44 yaitu dengan metode akrual penuh (full accrual method). Perusahaan mengakui kas masuk yang diterima dari pelanggan sebagai pendapatan, dan biaya yang dikeluarkan sebagai beban pokok penjualan. Untuk memastikan pengakuan pendapatan PT. Maura Lombok sudah sesuai dengan penerapan PSAK 44 dibuatkan tabel sebagai berikut:

Tabel 1.

Perbandingan Penerapan Perusahaan dengan Penerapan Sesuai PSAK No. 44

\begin{tabular}{|l|l|c|}
\hline \multicolumn{1}{|c|}{ Penerapan Perusahaan } & \multicolumn{1}{|c|}{$\begin{array}{c}\text { Penerapan Sesuai } \\
\text { PSAK No. 44 }\end{array}$} & $\begin{array}{c}\text { Sesuai / } \\
\text { Tidak Sesuai }\end{array}$ \\
\hline $\begin{array}{l}\text { Penjualan diakui sebagai } \\
\text { Uang muka perusahaan }\end{array}$ & $\begin{array}{l}\text { Penjualan diakui sebagai uang } \\
\text { muka perusahaan. }\end{array}$ & Sesuai \\
\hline $\begin{array}{l}\text { Harga jual dianggap tertagih } \\
\text { apabila jumlah pendapatan } \\
\text { uang muka oleh pembeli sudah } \\
\text { mencapai 30\% dari harga jual } \\
\text { yang ditetapkan. }\end{array}$ & $\begin{array}{l}\text { Harga jual dianggap tertagih apabila } \\
\text { jumlah pembayaran uang muka oleh } \\
\text { pembeli telah mencapai 20\% dari } \\
\text { harga jual dan } \\
\text { jumlah tersebut tidak dapat untuk } \\
\text { diminta kembali. }\end{array}$ & Sesuai \\
\hline $\begin{array}{l}\text { Pendapatan diakui apabila } \\
\text { adanya penandatanganan } \\
\text { perjanjian kantor atau akte jual } \\
\text { beli di depan notaris atau pihak } \\
\text { bank (bila KPR). }\end{array}$ & $\begin{array}{l}\text { Pendapatan diakui apabila: } \\
\text { (1) Pengalihan resiko dan manfaat } \\
\text { kepemilikan. }\end{array}$ & $\begin{array}{l}\text { (2) Pembeli telah melunasi } \\
\text { kewajibannya. } \\
\text { (3) Adanya perjanjian jual beli. }\end{array}$ \\
\hline
\end{tabular}

Tabel 2. Perhitungan Pengakuan Pendapatan dengan Metode Persentase Penyelesaian (Dalam Jutaan Rupiah)

\begin{tabular}{|c|c|c|c|c|c|}
\hline Tahun & $\begin{array}{c}\text { Tingkat } \\
\text { Persentase }\end{array}$ & $\begin{array}{c}\text { Estimasi } \\
\text { Pendapatan }\end{array}$ & Yang Diakui & $\begin{array}{c}\text { Yang } \\
\text { Telah } \\
\text { Diakui }\end{array}$ & Tahun Berjalan \\
\hline 2017 & $0 \%$ & Rp 35.550 & $\mathrm{Rp}$ & - & \\
\hline 2018 & $30 \%$ & $\mathrm{Rp} \quad 35.550$ & 10.665 & - & $\mathrm{Rp} 10.665$ \\
\hline
\end{tabular}

Tabel 3 Perhitungan Beban Pokok ( dalam jutaan rupiah)

\begin{tabular}{|c|c|c|c|c|c|c|c|}
\hline Keterangan & $\begin{array}{c}\text { Estimasi } \\
\text { Total } \\
\text { Cost } \\
\text { Proyek }\end{array}$ & $\begin{array}{c}\text { \% Uang } \\
\text { Muka }\end{array}$ & $\begin{array}{c}\text { Bagian } \\
\text { Cost } \\
\text { Atas } \\
\text { Penjulan }\end{array}$ & $\begin{array}{c}\text { \% } \\
\text { Penyelesaian }\end{array}$ & $\begin{array}{c}\text { HPP } \\
\text { Penjualan } \\
\mathbf{2 0 1 8}\end{array}$ & $\begin{array}{c}\text { HPP } \\
\text { Penjualan } \\
\text { tahun berjalan } \\
\text { 2018 }\end{array}$ & $\begin{array}{c}\text { Total } \\
\text { HPP } \\
\text { Tahun } \\
\text { Berjalan }\end{array}$ \\
\hline $\begin{array}{c}\text { Tanah \& } \\
\text { Konstruksi }\end{array}$ & $\begin{array}{c}\text { Rp } \\
21.330\end{array}$ & $55 \%$ & Rp 3.555 & $30 \%$ & Rp 3.519 & Rp 3.519 & Rp 3.519 \\
\hline
\end{tabular}

Pencatatan yang dilakukan perusahaan untuk mengakui pendapatan dan beban yang akan disajikan pada laporan posisi keuangan dan laporan laba rugi yaitu Kas pada penjualan sebesar Rp.19.387.057. 570, (Jurnal pada saat penerimaan uang dari pelanggan), dan beban pokok penjualan pada persediaan sebesar Rp.15.026.026.837, (Jurnal pada saat mencatat biaya yang dikeluarkan perusahaan) Berdasarkan pernyataan PSAK No. 44 
paragraf 26 dijelaskan bahwa seharusnya PT.Maura Lombok menggunakan metode persentase penyelesaian dalam mengakui pendapatannya, karena perusahaan telah memenuhi seluruh kriteria yang telah di tetapkan dalam PSAK No. 44. Sehingga pencatatan yang seharusnya dilakukan perusahaan berdasarkan PSAK No. 44 adalah kas pada pendapatan diterima dimuka sebesar 19.387.057. 570, (Jurnal pada saat penerimaan uang dari pelanggan), persediaan pada utang supplier/bank sebesar Rp.15.026.026.837, (Jurnal pada saat mencatat biaya yang dikeluarkan perusahaan).

Berdasarkan perhitungan tabel 1 dan tabel 2 tersebut diperoleh bahwa pendapatan yang boleh diakui berdasarkan metode persentase penyelesaian adalah sebesar Rp. 10.665.000.000, nilai ini diperoleh dari tingkat persentase penyelesaian yang diperoleh dari teknik sipil sebesar 30\% , dikali dengan estimasi pendapatan sebesar Rp.3.519.000.000 sehingga pencatatan untuk mengakui pendapatan yaitu Pendapatan diterima dimuka pada Penjualan sebesar Rp. 10.665.000.000, dan beban pokok penjualan yang boleh diakui dalam metode persentase penyelesaian adalah sebesar Rp.3.519.000.000, nilai ini didapat dari $(21.330 \mathrm{x} 55 \%$ x 30\%) sehingga pencatatan yang dilakukan untuk mengakui beban pokok penjualan adalah beban pokok penjualan pada penjualan sebesar Rp3.519.000.000.

Akibat kesalahan dalam penerapan metode pengakuan pendapatan dan beban yang dilakukan perusahaan berdampak pada laporan laba rugi dan laporan posisi keuangan, pada laporan laba rugi penjualan dan beban pokok penjualan disajikan terlalu besar. Sehingga diperlukan jurnal penyesuaian sebagai berikut yaitu penjualan pada pendapatan diterima dimuka sebesar Rp8.722.000.000, (jurnal untuk mengoreksi pendapatan, karena overstated), nilai tersebut di peroleh dari nilai pengakuan pendapatan awal sebelum menggunakan metode presentase penyelesaian (percentage-of-completion method), yaitu pendapatan yang diakui diawal sebesar

Rp.19.387.057.570 dikurangi dengan nilai pendapatan yang telah dihitung menggunakan metode presentase penyelesaian (percentage-of-completion method) yaitu sebesar Rp 10.665.000. Selisih dari hasil pengurangan tersebut sebesar 8.722.000.000. Selanjutnya dibuatkan jurnal penyesuaian untuk beban pokok penjualan yaitu persediaan pada beban pokok penjualan sebesar Rp. 11.507.000.000, (Jurnal untuk mengoreksi beban pokok penjualan, karena overstated). Nilai tersebut diperoleh dari selisih pengakuan beban pokok sebelum menggunakan metode (percentage-of-completion method) yaitu Rp.15.026.026.837 dikurangi setelah menggunakan metode persentase penyelesaian sebesar Rp3.519.000.000. Jurnal tersebut secara lebih jelas dapat disajikan dalam tabel sebagai berikut :

Tabel 4. Jurnal Penyesuaian (dalam jutaan rupiah)

\begin{tabular}{|lcccc|}
\hline \multicolumn{2}{|l|}{ Jurnal Penyesuaian (dalam jutaan rupiah) } & & & \\
\hline $\begin{array}{l}\text { Penjualan } \\
\text { Pendapatan Di terima dimuka }\end{array}$ & $\mathrm{Rp}$ & 8.722 & & \\
\hline $\begin{array}{l}\text { Persediaan } \\
\text { Beban Pokok Penjualan }\end{array}$ & $\mathrm{Rp}$ & 11.507 & & \\
\hline
\end{tabular}

\section{Kesimpulan}

Berdasarkan hasil dan pembahasan yang dilakukan oleh penulis dalam Analisis Metode Pengakuan Pendapatan dan Beban pada PT Maura Lombok dapat disimpulkan bahwa PT Maura Lombok dalam mengakui pendapatan dan beban menggunakan metode akrual penuh (Full accrual method), berdasarkan PSAK No. 44 seharusnya PT Maura Lombok menggunakan metode persentase penyelesaiaan (percentage of completion 
method). Perusahaan konstruksi seperti PT. Maura Lombok sangat tepat meggunakan metode persentase penyelesaian karena pendapatan dan beban dicatat sesuai dengan tingkat kemajuan penyelesaian kontrak dan tidak menunggu sampai kontrak diselesaikan. Jumlah pendapatan yang diakui didasarkan pada ukuran tertentu dari kemajuan penyelesaian kontrak. Dengan menggunakan metode akrual penuh (Full accrual method) PT Maura Lombok mengakui pendapatan sebesar Rp. 19.387.057.570, dan beban pokok penjualan sebesar 8.722.000.000, berdasarkan hasil perhitungan pendapatan dan beban menggunakan metode persentase penyelesaian, penjualan yang boleh diakui perusahaan sebesar Rp. Rp. 10.665.000.000 dan beban pokok penjualan sebesar Rp 3.519.000 Sehingga perusahaan harus membuat jurnal koreksi sebagai berikut yaitu penjualan pada pendapatan diterima dimuka sebesar 8.722.000.000 (Jurnal untuk mengoreksi pendapatan, karena overstated), dan persediaan pada beban pokok penjualan sebesar Rp 11.507.000.000, (Jurnal untuk mengoreksi beban pokok penjualan, karena overstated)

\section{Saran}

Berdasarkan hasil dari kesimpulan tersebut, disarankan kepada Manajer PT. Maura Lombok untuk memperhatikan penggunaan metode yang sesuai dengan PSAK 44. Pada perusahaan property penggunaan metode (Full accrual method) tidak tepat karena nilai pendapatan disajikan terlau besar manager seharusnya menggunakan metode persentase penyelesaian (percentage of completion method) dalam mengakui pendapatan dan beban sehingga pendapatan dan beban yang diakui tidak overstate. Dengan demikian laporan keuangan yang disajikan PT. Maura Lombok tidak diragukan keandalanya oleh pihak yang berkepentingan seperti investor. Laporan keuangan yang sudah diakui keandaalanya dapat memberikan informasi dan bahan pertimbangan bagi pihak yang berkepentingan dalam pengambilan keputusan.

\section{DAFTAR PUSTAKA}

Dewi Shinta, Andolita.2007. Akuntansi Aktivitas Pengembangan Real Estate Menurut PSAK No.44 Pada PT Ira Widya Utama Medan.Universitas Sumatera Utara Medan:Medan.

Earl K. Stice, James D. Stice dan K. Fred Skousen, 2004. Akuntansi Intermediate, Penerbit Salemba Empat, Jakarta.

E. Kieso, Donald, Jerry J, Weygandt and Teery D. Warfield, 20. 07. Accounting. Principles, Edisi 12 by: Salemba Empat

Dinfirafi Nandayani, Rachmi.2007.Tinjauan atas Penerapan Akuntansi Pengakuan Pendapatan pada Perusahaan Properti PT. Dam Utamasakti Prima.Universitas Widyatama Bandung:Bandung.

Ghozali,Imam dan Anis Chariri.2014.Teori Akuntansi International Financial Reporting System(IFRS). Edisi 4.Badan Penerbit Universitas Diponegoro:Semarang.

Halim, Abdul.2015.Akuntansi Keuangan Lanjutan.Mitra Wacana Media:Jakarta.

Martani, D.dkk.2016.Akuntansi Menengah Keuangan Menengah Berbasis PSAK.Salemba Empat:Jakarta.

Republik Indonesia.2007.Undang-Undang Nomor 40 Tahun 2007 tentang Perseroan Terbatas. Arkola:Surabaya.

Puspitasari, Pipit.2004.Analisis Akuntansi Penerapan Pendapatan dan Beban Menurut SAK ETAP pada KPRI Karya Husada di Dinas Kesehatan Kabupaten Lumajang.Sekolah Tinggi Ilmu Ekonomi (STIE) Widya Gama Lumajang:Lumajang.

Sanusi, Anwar.2011.Metodelogi PenelitianBisnis.SalembaEmpat:Jakarta. 
Standar Akuntansi Keuangan Efektif per 1 Januari 2017.2017.Ikatan Akuntan Indonesia:Jakarta.

Sugiyono.2012.Metode Penelitian pedidikan pendekatan kuantitatif, kualitatif, dan R\&D.Alfabet:Bandung.

Taufiq, Muchamad.2017.Aspek Hukum dalam Ekonomi.Media Nusa Creative:Malang.

Wahyuni, Tri.2003.Pengakuan Pendapatan dan Biaya pada PT. Pembangunan Perumahan Cabang V Semarang.Universitas Sebelas Maret Surakarta:Surakarta.

Wardani Sri, Atik.2006.Evaluasi Pengakuan Pendapatan atas Penjualan Angsuran Tahun 2004 dan 2005 pada UD Citra Jaya Motor.Universitas Sebelas Maret Surakarta:Surakarta.

Hajar, Ibnu. 2017. Analisis Metode Pengakuan Pendapatan Dan Beban Atas Perusahaan Real Estate Pada PT XYZ Sesuai Dengan PSAK No. 44. Ekonomi dan Bisnis, Politeknik Negeri Lampung: Lmapung

Zuhriyah, Firdatuz dkk. 2019. Analisis Penerapan Akuntansi Pengakuan Pendapatan Pada Perusahaan Properti "PT. Rojoland Indonesia Build". Sekolah Tinggi Ilmu Ekonomi Widya Gama Lumajang 